\title{
Respon Pertumbuhan dan Hasil Tanaman Kacang Tanah terhadap Pemberian Dosis Pupuk Hayati Di Lahan Podsolik
}

\section{(Growth and Yield Response of Peanut to Giving Biofertilizer Dosage on Podsolic Lands)}

\author{
M. Fauzi Noor ${ }^{1}$, Mahdiannoor $^{2)}$ \& Nur Hafizah ${ }^{3)}$ \\ Program Studi Agroteknologi, Sekolah Tinggi Ilmu Pertanian Amuntai \\ 1)fauziyanor123@gmail.com \\ ${ }^{2)}$ mahdi_186@yahoo.com \\ ${ }^{3)}$ fifi_bjm@yahoo.co.id
}

\begin{abstract}
ABSTRAK
Tanaman kacang tanah merupakan tanaman polong-polongan kedua terpenting setelah kedelai di Indonesia. Pertumbuhan dan hasil tanaman kacang tanah di lahan podsolik kurang baik, problema tanah podsolik adalah reaksi tanah yang masam, kandungan Al yang tinggi, unsur hara rendah, sehingga diperlukan pengapuran dan pemupukan serta pengelolaan yang baik agar tanah menjadi produktif dan tidak rusak. Pupuk hayati merupakan alternatif penggunaan pupuk. Penelitian ini dilaksanakan pada lahan podsolik di Desa Banua Tinggal Kecamatan Labuan Amas Selatan Kabupaten Hulu Sungai Tengah yang dimulai dari bulan April sampai Juli 2017. Penelitian bertujuan untuk (i) mengetahui respon pertumbuhan dan hasil kacang tanah terhadap pemberian pupuk hayati di lahan podsolik dan (ii) mendapatkan dosis pupuk hayati terbaik untuk pertumbuhan dan hasil kacang tanah di lahan podsolik. Penelitian ini menggunakan Rancangan Acak Kelompok (RAK) dengan 4 perlakuan dan 6 kelompok sehingga terdapat 24 satuan percobaan. Pemberian pupuk hayati yaitu $\left(h_{0}\right) 0 \mathrm{t} \cdot \mathrm{ha}^{-1}=0 \mathrm{~kg}$. petak ${ }^{-1},\left(h_{1}\right) 50 \mathrm{t} \cdot \mathrm{ha} \mathrm{a}^{-1}=7,5$ kg.petak ${ }^{-1},\left(h_{2}\right) 70$ t.ha $a^{-1}=10,5 \mathrm{~kg} \cdot$ petak $^{-1},\left(h_{3}\right) 90 \mathrm{t} \cdot \mathrm{ha}^{-1}=13,5 \mathrm{~kg}$. petak $^{-1}$. Variabel yang diamati adalah tinggi tanaman, jumlah daun, diameter batang umur saat berbunga, jumlah polong pertanaman, berat basah polong pertanaman dan berat 100 biji kering. Hasil penelitian menunjukan bahwa pemberian pupuk hayati berpengaruh terhadap pertumbuhan dan hasil tanaman kacang tanah dan perlakuan (h.) 90 t.ha ${ }^{-1}$ = 13,5 kg.petak ${ }^{-1}$ merupakan perlakuan yang terbaik untuk pertumbuhan dan hasil tanaman kacang tanah.
\end{abstract}

Kata kunci: Kacang tanah, pertumbuhan, hasil, lahan podsolik, pupuk hayati.

\section{ABSTRACT}

Peanut plants are the second most important leguminous plants after soybeans in Indonesia. The growth and yield of peanut plants on podsolic land are not good, the problem of podsolic soil is acidic soil reaction, high Al content, low nutrient content, so it needs liming and fertilization and good management so that the soil becomes productive and not damaged. Biofertilizer is an alternative use of fertilizer. This research was carried out on podsolic land in Banua Tinggal Village, Labuan Amas Selatan District, Hulu Sungai Tengah Regency, which began from April to July 2017. The study aimed to (i) determine the response of growth and yield of peanuts to the provision of biological fertilizers on podsolic land and ) get the best dosage of biofertilizer for growth and yield of peanuts on podsolic fields. This study used a Randomized Block Design (RBD) with four treatments and six groups so that there were 24 experimental

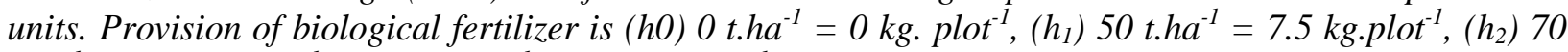
t.ha ${ }^{-1}=10.5 \mathrm{~kg} \cdot$ plot $^{-1}$, (h3) $90 \mathrm{t} \cdot \mathrm{ha}^{-1}=13.5 \mathrm{~kg} \cdot \mathrm{plot}^{-1}$. The variables observed were plant height, number of leaves, age stem diameter at flowering, number of plant pods, wet weight of plant pods, and weight of 100 dry seeds. The results showed that the administration of biofertilizer affected the growth and yield of peanut plants and treatment (h3) 90 t.ha-1 = $13.5 \mathrm{~kg}$.plot-1 was the best treatment for the growth and yield of peanut plants.

Keywords: Peanuts, growth, yield, podsolic land, biological fertilizer.

\section{PENDAHULUAN}

Sebagian besar penduduk Indonesia bermata pencaharian sebagai petani sehingga produksi pangan merupakan bahan yang menghidupi seluruh masyarakat. Jadi, sudah sewajarnya usaha pertanian harus kita tingkatkan, karena jumlah penduduk kian hari makin bertambah dan pangan senantiasa 
menjadi tuntutan kebutuhan semua orang (Tim Bina Karya Tani, 2009).

Kacang tanah merupakan salah satu tanaman pangan yang memiliki nilai gizi yang tinggi. Selain itu tanaman ini juga termasuk jenis tanaman pangan yang menjadi kegemaran masyarakat banyak sehingga perlu di kembangkan dan di tingkatkan produksinya untuk memenuhi permintaan masyarakat. Kacang tanah ini merupakan makanan yang sehat, karena mengandung protein nabati dan lemak yang dibutuhkan manusia, rasanya pun enak dan gurih. Biji kacang tanah dapat diolah sebagai kacang guring, kacang rebus, kacang atom, kacang telur, dan lain sebagainya (TIM Bina Karya Tani, 2009). Menurut data Badan Pusat Statistik Hulu Sungai Tengah , bahwa produksi kacang tanah pada tahun 2013 sebanyak 11.238 ton biji kering 2014 sebanyak 11.836 ton biji kering 2015 sebanyak 9.121 ton biji kering, dari data ini terlihat bahwa produksi kacang tanah mengalami penurunan (BPS Kal-Sel, 2016).

Tanah-tanah yang cocok untuk pertumbuhan kacang tanah, yaitu alluvial, regosol, grumosol, latosol, dan andosol. Pada tanah-tanah podsolik dan tanah yang mengandung banyak pasir swarsa, pertumbuhan kacang tanah kurang baik, kecuali jika tanah diberi tambahan pupuk organik atau kompos dalam jumlah cukup (Purwono dan Purnamawati, 2007). Menurut Hardjowigeno (2007), problema tanah ultisol dan oksisol (atau tanah-tanah podsolik) adalah reaksi tanah yang masam, kandungan Al yang tinggi, unsur hara rendah, sehingga diperlukan pengapuran dan pemupukan serta pengelolaan yang baik agar tanah menjadi produktif dan tidak rusak. Kondisi tanah podsolik mengakibatkan ketersediaan $\mathrm{P}$ dan $\mathrm{K}$ rendah, kation tertukar seperti $\mathrm{Ca}$ dan $\mathrm{Mg}$ menurun, serta defisiensi hara mikro khususnya $\mathrm{Zn}, \mathrm{Cu}$, dan Mo. Jenis tanah ini juga memiliki kandungan bahan organik yang rendah.

Ciri-ciri tanah podsolik yang menjadi kendala utama budidaya tanaman adalah $\mathrm{pH}$ rendah, kejenuhan $\mathrm{Al}$ dan kemungkinan besar $\mathrm{Fe}$ dan Mn aktif juga tinggi, lempung beraktivitas rendah dan bermuatan terubahkan, daya fosfat tinggi, kejenuhan basa rendah yang berarti tanah miskin hara makro $\mathrm{K}, \mathrm{Ca}$, dan $\mathrm{Mg}$, kadar bahan organik rendah dan ini pun terlonggok dalam lapisan tanah permukaan tipis, daya simpan air terbatas yang berarti tanah mudah mengalami kekeringan karena kelembaban cuaca menurun sedikit saja, dan jeluk (depth) efektif tanah terbatas karena tanah mempunyai horison longgokan lempung yang secara nisbi dangkal (Notohadiprawiro, 2006).

Salah satu alternatif untuk meningkatkan kadar unsur hara dalam tanah adalah memanfaatkan bahan organik yang berasal dari sisa tanaman dan binatang. Alternatif yang lain adalah memanfaatkan limbah organik yang berasal dari sampah kota, sampah rumah tangga, dan juga limbah hasil industri (Untung, 1997 dalam Danial dan Wahidah, 2008 ).

Penambahan pupuk hayati biofertil dapat memperbaiki sifat fisik, kimia, dan biologi tanaman sehingga peningkatan populasi bakteri tanah dan pertumbuhan tanaman kina. Pengoptimalan tanah sebagai suatu kekuatan biologis memerlukan beberapa pemahaman tentang kondisi yang sesuai untuk berbagai organisme tanah serta berbagai mikroorganisme menguntungkan dalam tanah, seperti bakteri penambat nitrogen dan bakteri pelarut fosfat (Antralina et. al., 2015). Penggunaan pupuk hayati tidak akan meninggalkan residu pada hasil tanaman sehingga aman bagi kesehatan manusia dan tentunya hasil panen atau produk makanan yang dihasilkan bisa kita kategorikan makanan sehat. Selain itu penggunaan pupuk hayati diharapkan dapat meningkatkan kesehatan tanah, memacu pertumbuhan tanaman dan meningkatkan produktifitas dan kualitas tanaman (Alfajri, 2015).

Pupuk hayati biofertil adalah pupuk yang dibuat dari mikroba yang mempunyai kekampuan untuk menyediakan unsur hara bagi tanaman, yang dibutuhkan nitrogen, fosfat, $\mathrm{Mg}, \mathrm{Zn}$, dan $\mathrm{Cu}$. Mikroba penambah nitrogen Rhizobium sp, hidup bekerja sama dengan tanaman dengan melibatkan aktivitas biokimia yang kompleks sehingga mampu menambah nitrogen dari udara. Nitrogen yang diperoleh digunakan oleh tanaman 
untuk pertumbuhan. Penerapan pupuk hayati Rhizobium pada budidaya tanaman kacangkacangan dapat menghasilkan rata-rata 13$50 \%$. Pada jenis-jenis mikroba yang nonsimbiotik umumnya mengeluarkan senyawa aktif tertentu (enzim) yang mampu meluruhkan unsur yang terkait dengah tanah sehingga dapat diserap oleh tanaman (Suwahyono, 2011).

Pupuk hayati memperbaiki tingkat kesuburan tanah dan meningkatkan asupan nutrien dan air pada kondisi tanah yang kritis. Pupuk hayati juga menghasilkan metabolit aktivator pertumbuhan tanaman dan mikroba dalam tanah, anti jamur, meningkatkan germinasi biji dan pertumbuan sistem perakaran. Penggunaan pupuk hayati efektif dalam memperkaya nilai ekonomis tanah dengan biaya yang murah dibandingkan pupuk kimia yang membahayakan lingkungan dan tergantung pada sumber energi tak terbarukan (Suwahyono, 2011).

$$
\text { Pupuk hayati mengandung }
$$

mikroorganisme bermanfaat untuk meningkatkan kesuburan tanah dan kualitas hasil tanaman, yaitu melalui peningkatan aktivitas biologi yang akhirnya dapat berinteraksi dengan sifat-sifat fisik dan kimia media tumbuh (tanah). Mikroorganisme yang umum digunakan sebagai bahan aktif pupuk hayati ialah mikroba penambat nitrogen, pelarut fosfat dan pemantap agregat (Hasnah dan Susanna, 2010).

Takaran terbaik abu sekam padi yang dapat memberikan tanggap pertumbuhan dan hasil tanaman kacang tanah pada lahan rawa lebak didapat pada perlakuan dosis 24 ton.ha ${ }^{-}$ ${ }^{1}$ atau setara dengan $2,304 \mathrm{~kg}$ petak $^{-1}$. Hasil penelitian Laiya (2013), perlakuan pupuk hayati terbaik yang ber respon pada pertumbuhan dan produksi jagung hibrida terdapat pada dosis pupuk hayati $50 \mathrm{~kg} / \mathrm{ha}^{-1}$ dan pupuk hayati diberikan pada saat tanaman berumur 14 dan 35 HST. Penelitian ini bertujuan untuk (i) mengetahui respon pertumbuhan dan hasil kacang tanah terhadap pemberian pupuk hayati di lahan podsolik dan (ii) mendapatkan dosis pupuk hayati terbaik untuk pertumbuhan dan hasil kacang tanah di lahan podsolik.

\section{METODE PENELITIAN}

Penelitian ini dilaksanakan di Desa Banua Tinggal Kecamatan Labuan Amas Selatan Kabupaten Hulu Sungai Tengah dari Maret - Mei 2017. Bahan yang digunakan antara lain benih kacang tanah Varietas Gundul Murakata, lahan podsolik, pupuk hayati Petro Biopertil, air dan pestisida alami. Alat yang dipakai antara lain parang, tugal, cangkul, meteran, timbangan, tali, gembor, alat tulis dan alat dokumentasi.

Penelitian ini merupakan percobaan yang dilaksanakan di lapangan dengan menggunakan Rancangan Acak Kelompok (RAK). Faktor yang diuji adalah dosis pupuk hayati $(\mathrm{H})$ sebanyak 4 taraf, yang terdiri dari $: \mathrm{h}_{0}=0 \mathrm{~kg} \cdot \mathrm{ha}^{-1}$ setara dengan $0 \mathrm{~g} \cdot$ petak $^{-1}, \mathrm{~h}_{1}=$ 50 kg.ha- ${ }^{-1}$ setara dengan 7.5 g.petak ${ }^{-1}, \mathrm{~h}_{2}=70$ kg.ha- ${ }^{-1}$ setara dengan 10.5 g.petak ${ }^{-1}$ dan $\mathrm{h}_{3}=$ 90 g.ha ${ }^{-1}$ setara dengan 13.5 g.petak ${ }^{-1}$. Pengelompokan percobaan berdasarkan kemiringan lahan percobaan, terdiri dari 6 kelompok, sehingga diperoleh 24 satuan percobaan. Setiap percobaan terdiri dari 4 tanaman sampel.

Pelaksanaan penelitian terdiri dari pengolahan tanah, penanaman benih kacang tanah, pemeliharaan, pemupukan dan panen. Pengamatan yang dilakukan adalah pengukuran peubah tinggi tanaman, diameter batang dan jumlah daun umur 14, 24, 34, dan 44 HST (hari setelah tanam) serta umur tanaman saat berbunga, jumlah polong pertanaman, berat polong basah pertanaman dan berat kering 100 biji. Analisa data yang dilakukan antara lain uji kehomogenan data, bila sudah homogen dari setiap perlakuan, kemudian dianalisis dangan analisis ragam menggunakan uji-F pada taraf nyata $5 \%$ dan 1\%. Apabila uji-F menunjukkan pengaruh nyata atau sangat nyata maka analisis dilanjutkan dengan uji jarak berganda duncan (DMRT) pada taraf nyata 5\% (Hanafiah, 2010).

\section{HASIL DAN PEMBAHASAN}

\section{Hasil \\ Tinggi Tanaman \\ Hasil analisis ragam menunjukkan bahwa perlakuan pemberian dosis pupuk hayati tidak memberikan respon pada umur}


14, 24 HST, tetapi memberikan respon terhadap tinggi tanaman kacang tanah umur 34 dan 44 HST. Hasil uji beda rata-rata tinggi tanaman kacang tanah pada umur 14, 24, 34, dan 44 HST dapat dilihat pada Tabel 1.

Tabel 1. Hasil uji beda rata-rata tinggi tanaman kacang tanah.

\begin{tabular}{ccccc}
\hline & \multicolumn{4}{c}{ Rata-rata tinggi tanaman $(\mathrm{cm})$} \\
\hline Perlakuan & $14 \mathrm{HST}$ & $24 \mathrm{HST}$ & $34 \mathrm{HST}$ & $44 \mathrm{HST}$ \\
\hline $\mathrm{h}_{0}$ & 9.17 & 12.21 & $25.83^{\mathrm{a}}$ & $27.66^{\mathrm{a}}$ \\
$\mathrm{h}_{1}$ & 14.83 & 21.63 & $26.45^{\mathrm{a}}$ & $28.29^{\mathrm{a}}$ \\
$\mathrm{h}_{2}$ & 12.50 & 17.50 & $27.70^{\mathrm{a}}$ & $30.20^{\mathrm{a}}$ \\
$\mathrm{h}_{3}$ & 10.08 & 19.46 & $42.95^{\mathrm{b}}$ & $44.45^{\mathrm{b}}$ \\
\hline
\end{tabular}

Keterangan: Nilai rata-rata yang diikuti oleh huruf yang sama pada kolom yang sama menunjukkan perlakuan tersebut tidak berbeda berdasarkan DMRT pada taraf $5 \%$.

Pada Tabel 3 terlihat bahwa pada umur 34 dan 44 HST rata-rata tinggi tanaman kacang tanah pada perlakuan $\mathrm{h}_{0}, \mathrm{~h}_{1}$, dan $\mathrm{h}_{2}$ tidak berbeda, tetapi berbeda dengan perlakuan $\mathrm{h}_{3}$. Perlakuan terbaik pemberian dosis pupuk hayati untuk peubah tinggi tanaman umur 34 dan 44HST adalah $\mathrm{h}_{3}$.

\section{Diameter Batang}

Hasil analisis ragam menunjukkan bahwa perlakuan pemberian dosis pupuk hayati memberikan respon pada umur 14,24 , 34 dan 44 HST. Hasil uji beda rata-rata diameter batang tanaman kacang tanah dapat dilihat pada Tabel 2 .

Tabel 2. Hasil uji beda rata-rata diameter batang kacang tanah

\begin{tabular}{ccccc}
\hline & \multicolumn{4}{c}{ Rata-rata diameter batang $(\mathrm{cm})$} \\
\hline Perlakuan & $14 \mathrm{HST}$ & $24 \mathrm{HST}$ & $34 \mathrm{HST}$ & $44 \mathrm{HST}$ \\
\hline $\mathrm{h}_{0}$ & $0.24^{\mathrm{a}}$ & $1.64^{\mathrm{a}}$ & $1.77^{\mathrm{a}}$ & $2.05^{\mathrm{a}}$ \\
$\mathrm{h}_{1}$ & $0.25^{\mathrm{a}}$ & $2.29^{\mathrm{a}}$ & $2.31^{\mathrm{a}}$ & $2.32^{\mathrm{a}}$ \\
$\mathrm{h}_{2}$ & $0.24^{\mathrm{a}}$ & $3.11^{\mathrm{ab}}$ & $3.14^{\mathrm{ab}}$ & $3.58^{\mathrm{ab}}$ \\
$\mathrm{h}_{3}$ & $0.27^{\mathrm{b}}$ & $3.47^{\mathrm{b}}$ & $3.57^{\mathrm{b}}$ & $3.75^{\mathrm{b}}$ \\
\hline
\end{tabular}

Keterangan: Nilai rata-rata yang diikuti oleh huruf yang sama pada kolom yang sama menunjukkan perlakuan tersebut tidak berbeda berdasarkan DMRT pada taraf $5 \%$.

Dari Tabel 4 terlihat bahwa pada umur 14 HST, perlakuan $\mathrm{h}_{3}$ berbeda dengan perlakuan lainnya. Perlakuan terbaik pemberian dosis pupuk hayati untuk peubah tinggi tanaman $14 \mathrm{HST}$ adalah $\mathrm{h}_{3}$. Pada umur 24 HST pada perlakuan $\mathrm{h}_{2}$ dan $\mathrm{h}_{3}$ tidak berbeda, tetapi berbeda dengan perlakuan $\mathrm{h}_{0}$ dan $\mathrm{h}_{1}$. Perlakuan terbaik pemberian dosis pupuk hayati untuk peubah tinggi tanaman 24 HST adalah $\mathrm{h}_{2}$ Pada umur 34 HST, perlakuan $h_{3}$ tidak berbeda dengan $h_{2}, h_{1}$ dan $h_{0}$. Perlakuan terbaik pemberian dosis pupuk hayati untuk peubah tinggi tanaman 34 HST adalah $\mathrm{h}_{2}$. Pada umur 44 HST polanya juga sama dengan umur 44 HST, sebagai perlakuan terbaik adalah $\mathrm{h}_{2}$.

\section{Jumlah Daun}

Hasil analisis ragam menunjukkan bahwa perlakuan pemberian dosis pupuk hayati memberikan respon pada umur 14,24 , 34 dan 44 HST. Hasil uji beda rata-rata jumlah daun tanaman kacang tanah dapat dilihat pada Tabel 3. Dari Tabel 3 terlihat bahwa umur 14, 24, 34 dan 44 HST, perlakuan $h_{3}$ berbeda dengan semua perlakuan lainnya. Perlakuan $\mathrm{h}_{3}$ merupakan perlakuan terbaik pemberian dosis pupuk hayati untuk peubah jumlah daun umur 14 ,

\section{4, 34 dan 44 HST.}

Tabel 3. Hasil uji beda rata-rata jumlah daun kacang tanah. 
M. Fauzi Noor, Mahdiannoor \& Nur Hafizah, Respon pertumbuhan dan hasil..

\begin{tabular}{ccccc}
\hline & \multicolumn{4}{c}{ Rata-rata jumlah daun (helai) } \\
\hline Perlakuan & 14 HST & 24 HST & 34 HST & 44 HST \\
\hline $\mathrm{h}_{0}$ & $24.29^{\mathrm{a}}$ & $15.20^{\mathrm{a}}$ & $31.03^{\mathrm{a}}$ & $80.05^{\mathrm{a}}$ \\
$\mathrm{h}_{1}$ & $24.64^{\mathrm{a}}$ & $14.42^{\mathrm{a}}$ & $28.92^{\mathrm{a}}$ & $81.01^{\mathrm{a}}$ \\
$\mathrm{h}_{2}$ & $26.21^{\mathrm{a}}$ & $16.46^{\mathrm{a}}$ & $39.79^{\mathrm{b}}$ & $81.93^{\mathrm{a}}$ \\
$\mathrm{h}_{3}$ & $35.40^{\mathrm{b}}$ & $21.98^{\mathrm{b}}$ & $56.98^{\mathrm{c}}$ & $114.83^{\mathrm{b}}$ \\
\hline
\end{tabular}

Keterangan: Nilai rata-rata yang diikuti oleh huruf yang sama pada kolom yang sama menunjukkan perlakuan tersebut tidak berbeda berdasarkan DMRT pada taraf $5 \%$.

\section{Umur Tanaman Saat Berbunga}

Hasil analisis ragam menunjukkan

tanaman saat berbunga. Hasil uji beda ratabahwa perlakuan pemberian dosis pupuk hayati memberikan respon pada umur rata umur tanaman saat berbunga tanaman kacang tanah dapat dilihat pada Tabel 4.

Tabel 4. Hasil uji beda rata-rata umur tanaman saat berbunga kacang tanah.

\begin{tabular}{cc}
\hline Perlakuan & Rata-rata umur tanaman saat berbunga \\
\hline $\mathrm{h}_{0}$ & $23.58 \mathrm{~b}$ \\
$\mathrm{~h}_{1}$ & $24.03 \mathrm{~b}$ \\
$\mathrm{~h}_{2}$ & $24.84^{\mathrm{c}}$ \\
$\mathrm{h}_{3}$ & $22.10^{\mathrm{a}}$ \\
\hline
\end{tabular}

Keterangan: Nilai rata-rata yang diikuti oleh huruf yang sama pada kolom yang sama menunjukkan perlakuan tersebut tidak berbeda berdasarkan DMRT pada taraf $5 \%$.

Dari Tabel 4 diatas terlihat bahwa perlakuan $\mathrm{h}_{3}$ berbeda dengan perlakuan $\mathrm{h}_{0}, \mathrm{~h}_{1}$ dan $\mathrm{h}_{2}$. Perlakuan terbaik pemberian dosis pupuk hayati untuk peubah umur tanaman saat berbunga adalah $\mathrm{h}_{3}$ yang merupakan perlakuan paling cepat berbunga.

\section{Jumlah Polong Pertanaman}

Hasil analisis ragam menunjukkan bahwa perlakuan pemberian dosis pupuk hayati memberikan respon terhadap jumlah polong pertanaman kacang tanah. Hasil uji beda rata-rata jumlah polong per tanaman kacang tanah dapat dilihat pada Tabel 5.

Tabel 5. Hasil uji beda rata-rata polong per tanaman kacang tanah.

\begin{tabular}{cc}
\hline Perlakuan & Rata-rata jumlah polong per tanaman sampel (buah) \\
\hline $\mathrm{h}_{0}$ & $47.75^{\mathrm{a}}$ \\
$\mathrm{h}_{1}$ & $49.00^{\mathrm{a}}$ \\
$\mathrm{h}_{2}$ & $52.21^{\mathrm{b}}$ \\
$\mathrm{h}_{3}$ & $57.46^{\mathrm{c}}$ \\
\hline
\end{tabular}

Keterangan: Nilai rata-rata yang diikuti oleh huruf yang sama pada kolom yang sama menunjukkan perlakuan tersebut tidak berbeda berdasarkan DMRT pada taraf $5 \%$.

Dari Tabel 5 diatas terlihat bahwa perlakuan $\mathrm{h}_{3}$ berbeda dengan semua perlakuan lainnya. Perlakuan $\mathrm{h}_{3}$ merupakan perlakuan terbaik dengan jumlah polong paling banyak.

\section{Berat Basah Polong Pertanaman}

Hasil analisis ragam menunjukkan bahwa perlakuan pemberian dosis pupuk hayati memberikan respon terhadap berat polong basah pertanaman kacang tanah. Hasil uji beda rata-rata berat basah polong per tanaman kacang tanah dapat dilihat pada Tabel 6.

Tabel 6. Hasil uji beda rata-rata berat basah polong per tanaman kacang tanah. 


\begin{tabular}{cc}
\hline Perlakuan & Rata-rata berat basah polong per tanaman $(\mathrm{g})$ \\
\hline $\mathrm{h}_{0}$ & $70.08^{\mathrm{a}}$ \\
$\mathrm{h}_{1}$ & $80.79^{\mathrm{ab}}$ \\
$\mathrm{h}_{2}$ & $85.92^{\mathrm{ab}}$ \\
$\mathrm{h}_{3}$ & $91.75^{\mathrm{c}}$ \\
\hline
\end{tabular}

Keterangan: Nilai rata-rata yang diikuti oleh huruf yang sama pada kolom yang sama menunjukkan perlakuan tersebut tidak berbeda berdasarkan DMRT pada taraf $5 \%$.

Dari Tabel 6 diatas terlihat bahwa perlakuan $\mathrm{h}_{3}$ berbeda dengan perlakuan lainnya. Perlakuan terbaik pemberian dosis pupuk hayati untuk peubah rata-rata berat basah polong per tanaman kacang tanah adalah $\mathrm{h}_{3}$ dengan berat basah polong paling berat.

\section{Berat 100 Biji Kering Pertanaman}

Hasil analisis ragam menunjukkan bahwa perlakuan pemberian dosis pupuk hayati memberikan respon terhadap berat 100 biji kering per tanaman kacang tanah dilihat pada Tabel 9.

Tabel 7. Hasil uji beda rata-rata berat 100 biji kering per tanaman kacang tanah

\begin{tabular}{cc}
\hline Perlakuan & Rata-rata berat 100 biji kering pertanaman $(\mathrm{g})$ \\
\hline $\mathrm{h}_{0}$ & $13.00^{\mathrm{a}}$ \\
$\mathrm{h}_{1}$ & $27.71^{\mathrm{c}}$ \\
$\mathrm{h}_{2}$ & $20.08^{\mathrm{ab}}$ \\
$\mathrm{h}_{3}$ & $22.83^{\mathrm{ab}}$ \\
\hline
\end{tabular}

Keterangan: Nilai rata-rata yang diikuti oleh huruf yang sama pada kolom yang sama menunjukkan perlakuan tersebut tidak berbeda berdasarkan DMRT pada taraf $5 \%$.

Dari Tabel 7 diatas dilihat bahwa perlakuan $\mathrm{h}_{3}$ tidak berbeda dengan perlakuan $\mathrm{h}_{2}$ dan $\mathrm{h}_{1}$ tetapi berbeda dengan perlakuan $\mathrm{h}_{1}$. Perlakuan h1 merupakan perlakuan terbaik untuk pemberian dosis pupuk hayati dengan berat 100 biji kering pertanaman paling berat.

\section{Pembahasan}

Berdasarkan analisis ragam terlihat bahwa tinggi tanaman kacang tanah dengan pemberian berbagai dosis pupuk hayati tidak memberikan respon pada umur 14 dan 24 HST. Hal ini disebabkan tanaman masih muda, belum memiliki perakaran yang sempurna, akibatnya akar belum bisa menyerap unsur hara dengan optimal. Menurut Yulistrarini (1991) dalam Djunaedy (2009) bahwa tanaman muda menyerap unsur hara dalam jumlah yang sedikit, sejalan dengan pertumbuhan tanaman, kecepatan penyerapan unsur hara pertanaman akan meningkat. Disamping itu proses dekomposisi mikroorganisme berjalan lambat. Hal ini berhubungan dengan laju perombakan bahan organik yang lambat, karena itu unsur hara disimpan dalam tanah dan dimineralisasi secara bertahap atau sinkronisasi antara waktu pelepasan unsur hara dan kebutuhan akan unsur hara tersebut tergolong rendah, dimana kualitas bahan organik sangat menentukan kecepatan proses dekomposisi dan mineralisasi bahan organik tersebut (Rahman, 2010).

Berdasarkan hasil analisis ragam bahwa tinggi tanaman kacang tanah pada umur 34, dan 44 HST memberikan respon hal ini karena perakaran kacang tanah sudah sempurna sehingga bisa menyerap unsur hara dengan optimal dan unsur hara yang terkandung dalam pupuk hayati sudah terurai dengan baik dalam tanah, sehingga akar tanaman kacang tanah mudah menyerap unsur hara yang terkandung didalam pupuk hayati tersebut. Jumlah daun merupakan efek dari pertumbuhan tanaman. Perlakuan pupuk hayati dan kompos menghasilkan jumlah daun yang besar, hal ini juga terkait dengan kandungan unsur yang dibutuhkan oleh tanaman untuk pertumbuhan vegetatif. Pada kedua perlakuan tersebut kandungan unsur $\mathrm{N}$, $\mathrm{P}$ dan $\mathrm{C}$ adalah paling tinggi dibandingkan 
perlakuan yang lain. Unsur $\mathrm{N}$ berguna untuk merangsang pertumbuhan tanaman secara keseluruhan, merangsang pertumbuhan vegetatif dan berfungsi untuk sintesa asam amino dan protein dalam tanaman. Dengan kandungan $\mathrm{N}$ dan $\mathrm{P}$ yang tinggi maka pertumbuhan daun dan pertumbuhan vegetatif tanaman akan lebih baik

Berdasarkan hasil analisis ragam pada variabel pengamatan jumlah daun dan diameter batang tanaman kacang tanah pada umur 14, 24, 34, dan 44 HST memberikan respon hal ini karena peningkatan tersebut disebabkan oleh adanya keberadaan mikroorganisme akibat adanya penambahan pupuk hayati ke tanah yang lebih banyak sehingga mampu mempercepat proses dekomposisi bahan organik yang nantinya dimanfaatkan oleh tanaman. Setyanti et.al. (2013), menyatakan bahwa pembentukan jumlah daun termasuk pada pertumbuhan vegetatif bersama dengan tinggi tanaman, pada pertumbuhan vegetatif nutrisi dan cahaya yang diperlukan lebih banyak dibutuhkan untuk pembentukan zat hijau daun (klorofil) pada tanaman kacang tanah.

Berdasarkan hasil analisis ragam pada variabel pengamatan umur tanaman saat berbunga menunjukkan bahwa perlakuan pemberian pupuk hayati memberikan respon terhadap tanaman saat berbunga. Hal ini karena unsur hara yang terkandung didalam pupuk hayati sudah terurai dengan baik dalam tanah, sehingga akar tanaman kacang tanah mudah menyerap unsur hara yang terkandung didalam pupuk hayati tersebut.

Selain unsur N, unsur $\mathrm{P}$ dan $\mathrm{K}$ juga dibutuhkan oleh tanaman kacang tanah untuk menunjang pertumbuhan dan hasil yang di mana unsur $\mathrm{P}$ berfungsi untuk menyusun komponen setiap sel hidup, membantu pembentukan protein dan mineral, merangsang pembentukan bunga, buah dan biji, bahkan mampu mempercepat pemasakan buah dan membuat biji lebih berbobot. Sedangkan unsur $\mathrm{K}$ berperan dalam pembentukan karbohidrat dan gula yang berfungsi untuk membuat kualitas bunga dan buah yang dihasilkan baik, dan juga untuk memperkuat kondisi tanaman agar tidak mudah terserang hama dan penyakit (Agromedia, 2007).
Berdasarkan hasil analisis ragam pada variabel pengamatan jumlah polong pertanaman, berat polong basah pertanaman, dan berat kering menunjukkan bahwa perlakuan dengan memberikan pupuk hayati pada taraf dosis memberikan respon. Dalam meningkatkan hasil dan produksi tanaman kacang tanah, kacang membutuhkan beberapa unsur hara penting seperti $\mathrm{N}$. Menurut Lakitan (1993) dalam Permanasari et.al., (2014) unsur $\mathrm{N}$ bagi tanaman adalah sebagai penyusun protein dan klorofil. Klorofil berfungsi untuk menangkap cahaya matahari yang berguna untuk pembentukan makanan dalam proses fotosintesis. Hasil dari fotosintesis digunakan oleh tanaman untuk pertumbuhan generatif tanaman seperti pembentukan polong dan biji tanaman. Dal hal ini dapat disimpulkan bahwa unsur hara $\mathrm{N}$ sangat berperan dalam menentukan jumlah polong, jumlah biji, berat polong basah dan berat biji kering tanaman kacang tanah.

Unsur P dan K juga dibutuhkan oleh tanaman kacang tanah untuk menunjang pertumbuhan dan hasil yang di mana unsur $\mathrm{P}$ berfungsi untuk menyusun komponen setiap sel hidup, membantu pembentukan protein dan mineral, merangsang pembentukan bunga, buah dan biji, bahkan mampu mempercepat pemasakan buah dan membuat biji lebih berbobot. Sedangkan unsur K berperan dalam pembentukan karbohidrat dan gula yang berfungsi untuk membuat kualitas bunga dan buah yang dihasilkan baik, dan juga untuk memperkuat kondisi tanaman agar tidak mudah terserang hama dan penyakit (Agromedia, 2007).

Apabila kondisi lingkungan tumbuh tidak mendukung maka potensi produksi yang tinggi dari varietas unggul tersebut tidak dapat tercapai. Sebagai gambaran kondisi lingkungan tumbuh seperti keadaan $\mathrm{pH}$ tanah yang netral yaitu $6.52 \%$, kandungan C-Organik yang rendah yaitu $1.638 \%$, unsur hara nitrogen total yang sedang yaitu $0.218 \%$, unsur hara P-Total yang rendah yaitu $14.475 \mathrm{mg} 100 \mathrm{~g}^{-1}$, unsur hara K-Total yang sedang yaitu $0.332 \mathrm{mg}$ $100 \mathrm{~g}^{-1}$. Tim Bina Karya Tani (2009), mengatakan bahwa tanaman kacang tanah menghendaki keadaan $\mathrm{pH}$ antara 6-6,5 (agak netral). 
Menurut Tim Bina Karya Tani (2009), tanaman kacang tanah menghendaki lahan yang gembur, agar perkembangan akarnya berlangsung dengan baik, ginoforanya mudah masuk kedalam tanah untuk membentuk polong dan pemanenannya mudah.

Salah satu faktor lingkungan yang berpengaruh terhadap viabilitas suatu bakteri adalah $\mathrm{pH}$. $\mathrm{pH}$ tanah adalah salah satu yang mempengaruhi pertumbuhan bakteri dalam pupuk hayati. Bakteri memerlukan suatu $\mathrm{pH}$ optimum sekitar 6,0 - 7,5. Pengaruh $\mathrm{pH}$ terhadap pertumbuhan bakteri ini berkaitan dengan aktivitas enzim. Enzim ini dibutuhkan oleh beberapa bakteri untuk mengkatalis reaksi-reaksi yang berhubungan dengan bakteri. Apabila pH dalam medium atau lingkungan tidak optimal maka mengganggu kerja enzom-enzim dan akhirnya menganggu pertumbuhan bakteri Rohman et. al., (2016).

Pupuk hayati salah satu alternatif pupuk yang dapat mengurangi ketergantungan penggunaan pupuk kimia. Pupuk hayati merupakan bahan yang mengandung mikroba yang dapat mengolah bahan-bahan organik menjadi bahan anorganik yang berguna bagi tanaman. Mikroba dalam pupuk hayati memiliki kemampuan penambat nitrogen dan melarutkan fosfat sehingga dapat meningkatkan ketersedian unsur hara. Salah satu peran pupuk hayati yaitu penambatan nitrogen. Bakteri penambat nitrogen $(\mathrm{N})$ memiliki kemampuan meningkatkan efisiensi penggunaan $\mathrm{N}$ tersedia dalam tanah. Bakteri tersebut menggunakan nitrogen bebas untuk sintesis sel protein dimana protein tersebut akan mengalami proses mineralisasi dalam tanah. Bakteri penambat nitrogen berkontribusi terhadap ketersediaan $\mathrm{N}$ untuk tanaman. Aplikasi pupuk hayati penambat nitrogen dengan menggunakan Azotobacter sp. Azotobacter sp mempunyai kemampuan memfiksasi $\mathrm{N}$ dari udara. Pembuatan bakteri penambat nitrogen sebagai pupuk hayati membutuhkan media pembawa. Penggunaan media pembawa berfungsi untuk mengemas agen biologis memperpanjang waktu simpan agen biologis menumbuhkan dan memudahkan inokulum digunakan kembali di lapangan. Media pembawa berperan dalam menjaga viabilitas agen hayati. Pembuatan pupuk hayati harus mempertimbangkan media pembawa yang dikomposisikan. Media pembawa harus mengandung komponen penting yang mendukung daya viabilitas dan pertumbuhan mikroba yang diinokulasi ke dalamnya. Pengkomposisian pupuk hayati berbahan dasar media pembawa harus mengandung unsur hara organik berupa nitrogen, karbon organik, fosfor, kalium, dan unsur hara lainnya. Unsur tersebut dapat diproses oleh mikroba menjadi bahan anorganik yang dapat dimanfaatkan oleh tanaman. Serbuk kayu dan tanah dapat dijadikan sebagai bahan pembawa dikarenakan terdapat unsur $\mathrm{N}$ yang tinggi, serbuk kayu dapat menyimpan zat hara dalam tanah, sedangkan pakis memiliki aerasi dan draenasi yang baik. Kombinasi media pembawa bakteri penambat nitrogen diaplikasikan pada tanaman kacang tanah (Arachis hypogea L). Penggunaan kacang tanah dikarenakan salah satu tanaman pangan yang memiliki komoditas tinggi dan teknik budidaya yang mudah dan relatif cepat. Oleh karena itu, penting dilakukan penelitian mengenai pengaruh kombinasi media pembawa bakteri penambat nitrogen Azotobacter $s p$ terhadap peningkatan pertumbuhan tanaman kacang tanah Rohman et. al., (2016).

Pupuk hayati mengandung hara (termasuk $\mathrm{N}$ ) dalam jumlah cukup banyak dan sifatnya cepat tersedia bagi tanaman sedangkan pupuk hayati akan melepaskan hara yang lengkap (baik makro maupun mikro) dalam jumlah tidak tentu dan relatif kecil selama proses mineralisasi, sehingga dengan menambah pupuk hayati tersebut mampu mendukung dalam menyediakan unsur hara bagi tanaman. Kadar Nitrogen total dalam tanah tersebut terus mengalami penurunan selaras dengan pertumbuhan tanaman. Kadar Nitrogen di dalam tanah juga akan semakin berkurang. Hal ini dikarenakan semakin meningkat pertumbuhan suatu tanaman, maka kebutuhan akan unsur Nitrogen akan semakin meningkat, terutama pada fase pertumbuhan vegetatif Rohman et. al., (2016). 
Selain unsur nitrogen yang dapat meningkatkan laju fotosintesis tanaman yang dapat memacu pertumbuhan tanaman. Unsur hara fosfor (P) juga penting dalam hal transportasi hara dari akar ke daun translokasi asimilat dari daun keseluruh jaringan tanaman (Andi et.al., 2012).

\section{KESIMPULAN}

Berdasarkan hasil penelitian maka dapat diambil kesimpulan pertumbuhan dan hasil tanaman kacang tanah (Arachis hypogaea L.) terhadap pemberian dosis pupuk hayati di lahan podsolik memberikan respon terhadap tinggi tanaman 34 dan 44 HST, jumlah daun pada umur 14, 24, 34 dan 44 HST, umur saat berbunga, jumlah polong pertanaman, berat polong basah, jumlah biji dan berat biji kering pertanaman. Sedangkan dosis pupuk hayati terbaik untuk pertumbuhan dan hasil tanaman kacang tanah (Arachis hypogaea L.) pada lahan podsolik yaitu dengan dosis $\mathrm{h}_{3} 90 \mathrm{~g}$.ha ${ }^{-1}$ setara dengan 13.5 g.petak ${ }^{-1}$

\section{DAFTAR PUSTAKA}

Antralina, M., Dewi Kania. dan Joko Santosa. 2015. Pengaruh pupuk hayati terhadap kelimpahan bakteri penambat nitrogen dan perumbuhan tanaman kina Klon Cib.5. Jurnal Penelitian Teh dan Kina Vol. 18 No. 2.

Alfajri, A. 2015. Manfaat Pupuk Hayati (Biofertilizer) untuk Peningkatan Produktifitas dan Kualitas Pertanian. http://www.wongtani.tk/2015/05/manf aat-pupuk-hayati-biofertilizer.html Diakses tanggal 10 Januari 2017.

Agromedia. 2007. Petunjuk Pemupukan. PT. Agromedia. Jakarta.

Andi, I.L., Jumini. Dan Syafrudin. 2012. Pertumbuhan dan hasil tanaman kacang tanah (Arachis hypogaea L.) akibat pengaruh dosis pupuk $N, P$ dan kondisi media tanam tercemar hidrokarbon. Jurnal Agrista Vol. 17 No. 3. Banda Aceh.
BPS Kal-Sel. 2016. Survei Pertanian Produksi Tanaman Padi dan Palawija Kalimantan Selatan 2016 dan 2015. http://kalsel.bps.go.id. Diakses pada 10 Januari 2016.

Danial, M. Nur, A. S. T dan Wahidah, S. 2008. Pemanfaatan zeolit dan bokashi ampas tahu untuk menekan konsentrasi nikel dan meningkatkan pertumbuhan baby corn pada tanah tambang di Soroako. Jurnal Chemica Vol. 9 No. 2.

Djunaedy, A. 2009. Pengaruh jenis dan dosis pupuk bokashi terhadap pertumbuhan dan hasil kacang panjang ( Vigna sinensis L.). Jurnal Agrovigor Vol. 2 No.1

Hardjowigeno, S. H. 2005. Ilmu Tanah. Akademika Pressindo. Jakarta.

Hanafiah, K. A. 2010. Rancangan Percobaan. RajaGrafindo Persada. Jakarta.

Laiya, R., Muhammad, I. B. dan Nurmi. 2013. Pertumbuhan dan produksi jagung hibrida melalui pemberian pupuk hayati. Seminar Hasil Penelitian. Program Studi Agroteknologi Fakultas Pertanian UNHAS. Makassar.

Mahdiannoor. 2013. Tanggap pertumbuhan dan hasil tanaman kacang tanah (Arachis hypogea L.) terhadap pemberian abu sekam padi pada lahan rawa lebak. Jurnal Ziraa'ah Vol. 37 No. 2.

Notohadiprawiro, T. 2006. Budidaya organik : suatu sistem pengusahaan lahan bagi keberhasilan program transmigrasi pola pertanian lahan kering. Makalah Ilmu tanah. Universitas Gadjah Mada.

Purwono dan Purnamawati, H. 2007. Budidaya 8 Jenis Tanaman Unggul. Penebar Swadaya. Jakarta.

Permanasari, I. Irfan, M dan Abizar. 2014. Pertumbuhan dan hasil kedelai ( 
Glycine max L.) Dengan pemberian rhizobium dan pupuk urea pada media gambut. Jurnal Agroteknologi Vol. 5 No. 1.

Rahman, RF. 2010. C-Organik dan Bahan Organik. http://blog.ub.ac.id. Diakses tanggal 30 Agustus 2017

Rohman N., Muslihatin W. dan Nurhidayati T. 2016. Pengaruh kombinasi media pembawa pupuk hayati bakteri penambat nitrogen terhadap $\mathrm{pH}$ dan unsur hara nitrogen dalam tanah. Jurnal Sains dan Seni ITS Vol. 4. NO. 7. Surabaya.

Setyanti, Y. H, S. Anwar dan W. Slamet. 2013. Karakteristik fotosintetik dan serapan fosfor hijauan alfalfa (Medicago sativa) pada tinggi pemotongan dan pemupukan nitrogen yang berbeda. Animal Agriculture Vol. 2 No. 1.

Hasnah dan Susanna. 2010. Aplikasi pupuk hayati dan kandang pengendalian lalat bibit pada tanaman kedelai. Jurnal Floratek Vol. 5 No. 2.

Suwahyono, U. 2011. Petunjuk Praktis Penggunaan Pupuk Organik Secara Efektif dan Efisien. Penebar Swadaya. Jakarta.

Tim Bina Karya Tani. 2009. Budidaya Tanaman Kacang Tanah. CV. Yrama Widya. Bandung. 